\title{
Cutaneous Anthrax: Evaluation of 27 Cases
}

\section{Deri Șarbonu: 27 Olgunun Deg̃erlendirilmesi}

\author{
Tug̃çe ȘAHIN'(ID), Ayșe ÇEVIRME'(IID) \\ ${ }^{1}$ Department of Public Health Nursing, Faculty of Health Sciences, Sakarya University, Sakarya, Turkey
}

Cite this article as: Şahin T, Çevirme A. Cutaneous anthrax: evaluation of 27 cases. FLORA 2020;25(4):572-8.

\begin{abstract}
Introduction: While the incidence of anthrax is decreasing in Turkey, it is still endemic in some regions of the country. In this study, it was aimed to develop preventive methods by determining the characteristics of cutaneous anthrax after assessing the literature over the last six years (2013-2019) of cutaneous anthrax cases in Turkey.

Materials and Methods: The studies carried out in the last six years on cutaneous anthrax were examined retrospectively. Diagnosis, physical examinations, vital signs, laboratory results, medical treatments of the evaluated cases were performed and tables on demographic characteristics were developed.

Results: Patients' age ranged from 8 to 65 years. A total of 13 patients (48.1\%) who were assessed were males. The source of infection was contact with infected animal and its products in 23 cases (85.2\%), husbandry in 2 cases (7.4\%), contact with infected blood in one case (3.7\%), and being in the same environment with an anthrax diagnosed patient in one case (3.7\%). As a result of microbiological investigations, it was found out that 10 patients (37\%) had Bacillus anthracis. All patients received penicillin treatment. Only three patients were surgically treated. Treatment resulted in recovery in 26 cases.
\end{abstract}

Conclusion: In order to prevent the disease, preventive measures such as training of risky individuals dealing with animal husbandry and vaccination of animals will reduce the incidence of the disease.

Key Words: Cutaneous anthrax; Bacillus anthracis; Turkey

\section{ÖZ}

\section{Deri Șarbonu: 27 Olgunun Deg̃erlendirilmesi}

\author{
Tug̃çe ȘAHIN' ${ }^{1}$ Ayșe ÇEVIRME ${ }^{1}$
}

${ }^{1}$ Sakarya Üniversitesi, Sag̃lık Bilimleri Fakültesi, Halk Sag̃lıg̃ı Hemșirelig̃i Anabilim Dalı, Sakarya, Türkiye

Giriş: Şarbon, Türkiye'de insidansı azalmakla beraber, ülkemizin bazı bölgelerinde halen endemik olarak karşılaşılan bir zoonozdur. Bu çalışmada Türkiye'de görülen deri şarbonu vakalarının son altı yıldaki (2013-2019) literatür taraması yapılarak deri şarbonunun karakteristiğinin belirlenmesi ve önleyici girişimlerin geliştirilmesi amaçlanmıştır. 
Materyal ve Metod: Deri şarbonu ile ilgili son altı yılda yapılan çalışmalar geriye dönük olarak incelenmiştir. Değerlendirilen olguların fizik muayeneleri, vital bulguları, laboratuvar sonuçları, tıbbi tedavileri ve demografik özellikleri ile ilgili tablolar oluşturulmuştur.

Bulgular: Hastaların yaşları 8-65 yaş arasında değişmektedir. Değerlendirilen 27 olgunun 13'ü (\%48.1) erkek hastadır. 23 olguda (\%85.2) hayvan ve hayvan ürünleriyle temas, iki olguda (\%7.4) hayvancılık, bir olguda (\%3.7) şarbon tanısı almıs hasta kanı ile temas, bir olguda (\%3.7) ise şarbon tanısı almıs hasta ile aynı ortamda bulunma öyküsü vardır. Mikrobiyolojik incelemeler sonucu 10 hastada (\%37) şarbon basili saptanmıştır. Hastaların tümüne antibiyotik tedavisi uygulanmıs, üç hastaya da cerrahi olarak müdahale edilmiştir. Tedavi 26 olguda şifa ile sonuçlanmıştır.

Sonuç: Hastalığın önlenmesi amacıyla hayvancılık ile uğraşan riskli bireylerin eğitilmesi, hayvanların aşılanması gibi önleyici tedbirler hastalığın görülme sıklığını azaltacaktır.

Anahtar Kelimeler: Deri şarbonu; Bacillus anthracis; Türkiye

\section{INTRODUCTION}

Anthrax is an infection caused by Bacillus anthracis, it is essentially an infection of herbivorous animals (e.g. sheep, goat or cattle), and it can infect people through contact with meat and meat products of infected animals ${ }^{[1]}$. The incidence of anthrax cases in the world is going down, but after the anthrax spores sent to the United States by mail in 2001, it has come up again $^{[2,3]}$. Anthrax occurs mainly in three different clinical forms in humans; lung, gastrointestinal and cutaneous ${ }^{[4]}$. Pulmonary (lung) anthrax is caused by the inhalation of Bacillus anthracis spores, and gastrointestinal anthrax is seen as a result of consuming infected meats ${ }^{[5]}$. Cutaneous anthrax occurs when spores are inoculated into small wounds, abrasions, etc. on the skin after direct contact with the infected animal's skin, flesh and wool ${ }^{[6]}$. In some cases, Bacillus anthracis may blend into the circulation and this may result in some deadly diseases such as pneumonia, meningitis and antrax sepsis. Cutaneous anthrax is the most common and benign type with a rate of $95 \%$. It is reported that $10-20 \%$ of cutaneous anthrax cases may result in death if they are not treated ${ }^{[7]}$. In typical cutaneous anthrax cases, lesions are seen in the contact area after an incubation period of 1-9 days ${ }^{[8]}$. In cases of severe anthrax, oedema may occur in the extremities or on the entire trunk from the neck to the groin. This condition is called malignant oedema, and it is associated with inflammation of the $\operatorname{skin}^{[9]}$. In untreated patients, gram-positive bacilli may be seen in the Gram staining of the lesion and the diagnosis is confirmed ${ }^{[8]}$.
In cases of naturally transmitted anthrax, strains of Bacillus anthracis are susceptible to penicilin. Thus, penicillin, ampicillin, cefazolin and macrolides may be used for treatment ${ }^{[10,11]}$. Anthrax is a public health problem in Turkey, especially in areas where traditional farming is performed ${ }^{[12]}$. Anthrax cases are common in our country, in Eastern and Southeastern Anatolia regions where animal husbandry is widespread ${ }^{[13]}$. According to the latest data from Turkey Vector and Zoonotic Diseases Department in 2017, eight cases were declared in Kars which is a province in Eastern Anatolia Region, where stock farming is widely carried out ${ }^{[14]}$. This problem, which still continues today, has a significant place in terms of public health.

In this study, it was aimed to determine the characteristics of cutaneous anthrax cases which are endemic in Turkey. It was also aimed to develop preventive methods in order to increase the awareness and information levels of people who are at risk of getting the disease.

\section{MATERIALS AND METHODS}

From the 14 different studies evaluated, a total of 27 cutaneous anthrax cases were examined. Sex of the cases, the area of transmission and whether the cases had any history of contact with the source of infection were all examined. Clinical signs and symptoms, treatment methods, microbiology results of the patients were recorded, and evaluation results were tabulated based on patient characteristics.

Cutaneous anthrax, Bacillus anthracis and Turkey keywords were scanned between the dates of 
September 2018 and February 2019. Cutaneous anthrax cases in the last six years (2013-2019) in Google Academic and Chrome databases were found enough, and 27 different cutaneous anthrax cases were evaluated.

\section{RESULTS}

Demographical and clinical features of the evaluated cutaneous anthrax cases were summarized in Table 1, Table 2 and Table 3. In Table 1 , there are data on the sex, infection sources and lesion localizations of the cases. The total number of cases assessed in the study was 27, and 13 of them (48.1\%) were males. Four of the assessed cases gave no information about their ages, yet, the given age range was between 8-65. Infection sources were histories of contact with animals and their products in 23 cases (85.2\%), animal husbandry in 2 cases (7.4\%), contact with diseased blood in one case (3.7\%) and being in the same circumstances with the patient who was diagnosed with anthrax in one case (3.7\%). Localization of the lesion was the head and neck region in three cases $(11.1 \%)$,

Table 1. Findings on sex, the infection source and localization of the lesions in 27 cases of cutaneous anthrax

\begin{tabular}{lcc} 
& Number of patients $(\mathbf{n}=\mathbf{2 7})$ & Percentage $(\%)$ \\
\hline Male & 13 & 48.1 \\
Female & 14 & 51.9 \\
Infection source & & 85.2 \\
$\quad$ Contact with the infected animal and animal products & 23 & 7.4 \\
$\quad$ Husbandry & 2 & 3.7 \\
Contact with the blood of anthrax diagnosed patient & 1 & 3.7 \\
Having the same environment with the infected patient & 1 & 11.1 \\
Lesion localization & & 85.2 \\
$\quad$ Head-neck & 3 & 3.7 \\
Hand-arm & 23 & 1 \\
Abdomen & &
\end{tabular}

Table 2. Vital signs, laboratory findings, microbiologic examination and treatment methods of the 27 cutaneous anthrax cases

\begin{tabular}{lcc} 
& Number of patients $(\mathbf{n}=\mathbf{2 7})$ & Percentage $(\%)$ \\
\hline Clinical findings and laboratory & & 44.4 \\
Temperature & 12 & 3.7 \\
Arterial blood pressure $(<120 / 80)$ & 1 & 11.1 \\
Neutrophilia $(>50-70 \%)$ & 3 & 18.6 \\
AST $(>0-35$ U/L) & 5 & 11.1 \\
ALT $(>0-45$ U/L) & 3 & 7.4 \\
LDH $(>0-248$ U/L) & 2 & 3.7 \\
Total bilirubin $(>0.3-1.2 \mathrm{mg} / \mathrm{dL})$ & 1 & 3.7 \\
Direct bilirubin $(>0-, 0-0.2)$ & 1 & 25.9 \\
Sedimentation $(>20 \mathrm{~mm} / \mathrm{s})$ & 7 & 37 \\
CRP $(>5-10$ mg/L) & 10 & 44.4 \\
WBC $\left(>10.000 / \mathrm{mm}^{3}\right)$ & 12 & 25.9 \\
Microbiologic examination & & 11.1 \\
Gram-positive stain & 7 & 100 \\
Polimerase chain reaction & 3 & 11.1 \\
Treatment & & 96.3 \\
Antibiotics & 27 & \\
Surgery & 3 & FLORA 2020;25(4):572-578 \\
Recovery & 26 & \\
& & \\
\end{tabular}


Table 3. Contamination region of 27 cases and distribution according to years.

\begin{tabular}{|c|c|c|c|c|c|}
\hline & $\begin{array}{l}\text { Number of patients } \\
(n=27)\end{array}$ & $\begin{array}{c}\text { Percentage } \\
(\%)\end{array}$ & & $\begin{array}{l}\text { Number of patients } \\
\qquad(n=27)\end{array}$ & $\begin{array}{c}\text { Percentage } \\
(\%) \\
\end{array}$ \\
\hline Contamination region & & & Distr. acc. to years & & \\
\hline Trabzon & 3 & 11.1 & 2013 & 9 & 33.2 \\
\hline Van & 1 & 3.7 & 2014 & 1 & 3.7 \\
\hline Edirne & 1 & 3.7 & 2015 & 3 & 11.1 \\
\hline Gaziantep & 5 & 18.6 & 2016 & 5 & 18.6 \\
\hline Kayseri & 1 & 3.7 & 2017 & 3 & 11.1 \\
\hline Ankara & 2 & 7.4 & 2018 & 5 & 18.6 \\
\hline Hakkari & 1 & 3.7 & 2019 & 1 & 3.7 \\
\hline Siirt & 1 & 3.7 & & & \\
\hline Yozgat & 1 & 3.7 & & & \\
\hline Erzurum & 6 & 22.2 & & & \\
\hline Bursa & 1 & 3.7 & & & \\
\hline Diyarbakır & 4 & 14.8 & & & \\
\hline
\end{tabular}

hand and arm region in 23 cases (85.2\%) and abdominal region in one case (3.7\%). Vital signs, laboratory findings, microbiological examination and treatment methods were given in Table 2. On the evaluation of vital signs, 12 patients (44.4\%) were recorded as having high fever. Arterial blood pressure was below normal values in a patient (3.7\%). Neutrophil values were found to be higher than normal values $(50-70 \%)$ in three patients (11.1\%). Of the five patients (18.6\%) whose liver enzymes were checked, AST level was found to be high (normal value 0-35 U/L) and ALT (normal value 0-45 U/L) was found to be high in three patients (11.1\%). Another liver enzyme LDH (normal 0-248 U/L) was found to be high in two patients (7.4\%). Total bilirubin (normal $0.3-1.2 \mathrm{mg} / \mathrm{dL}$ ) was high in one patient (3.7\%). Direct bilirubin (normal 0.0-0.2 mg/dL) was high in one patient (3.7\%). Sedimentation levels of seven patients (25.9\%) with known sedimentation levels exceeded the normal value (> $20 \mathrm{~mm}$ ). Among the assessed cases, 10 of them (37\%) were reported as having a high CRP value (C-reactive protein) (normal value $5-10 \mathrm{mg} / \mathrm{L}$ ). White blood cell (WBC) values of 12 patients $(44.4 \%)$, whose values were known, were found to be higher than $10.000 / \mathrm{mm}^{3}$. As a result of microbiological examinations, a total of $10 \mathrm{pa}-$ tients (37\%) had final diagnosis. All the patients were given antibiotic treatment. Three of them (11.1\%) had surgical operation as well as antibiotic treatment. One of the patients (3.7\%) lost his life while 26 of them (96.3\%) recovered. Table
3 shows the distribution of cutaneous anthrax between the years 2013-2019 and the place of contamination. On examining the contamination places, it was seen that six (22.2\%) of the 27 cases were in Erzurum province. Other patients were in Trabzon, Van, Edirne, Gaziantep, Kayseri, Ankara, Hakkari, Siirt, Yozgat, Bursa, Diyarbakır. When cases were examined according to years, it was seen that there were nine cases $(33.2 \%)$ in 2013 , one case (3.7\%) in 2014, three cases $(11.1 \%)$ in 2015 , five cases $(18.6 \%)$ in 2016 , three cases (11.1\%) in 2017, five cases (18.6\%) in 2018 and one case (3.7\%) in 2019.

\section{DISCUSSION}

Upon the examination of demographical features of 27 cases, it is seen that sex differences and ages may have an assosciation with anthrax cases and not only adults but also children may get infected. In our study, it is noteworthy that three of the 27 cases were children, and that the children were also at risk. In a study by Aydin et al. (2018), 48 children have been evaluated in the pediatric emergency and infection outpatient clinics in the region upon the death of a 36-year-old patient from Bacillus anthracis sepsis ${ }^{[15]}$. Even if people do not deal with slaughter and similar works, the fact that sick animals and their wastes are not left in the area causes this risk. In the study of Yesilbağ and Kader (2014) including the case of a 16-year-old male patient diagnosed with anthrax, it has been emphasized that some measures should be taken, such as 
quarantine and burying the dead anthrax infected animals, in order to prevent an epidemic ${ }^{[6]}$. Mwakapeje et al. (2018), in their case-control study to prevent cutaneous anthrax risk factors and cutaneous anthrax in Northern Tanzania, have noted that dead anthrax infected animals should be destroyed (preferably incineration) by appropriate methods ${ }^{[16]}$. Both studies support our results asserting that contact with the animals and taking precautions should be taken seriously.

Human to human transmission is rarely seen, yet there is still a possibility of contamination by indirect and direct contact with infected wounds and discharge ${ }^{[6]}$. In our study, a patient who was diagnosed with cutaneous anthrax although she was not in direct contact with the animal was infected by contact with the infected blood. Another patient was diagnosed with cutaneous anthrax although she had no direct contact, she was reported just to live in the same area with the infected people and she was treated accordingly. It was seen that there were contact with sick animals in 23 of the cases. It was seen that there was husbandry in two cases. Cutaneous anthrax cases are generally reported as occupational diseases and they occur in farmers, butchers, wool separators, veterinarians, animal and animal hair dealers who are in direct contact with animal and animal products ${ }^{[1]}$. Lesions on the skin generally appear in the exposed areas of the body such as hands, arms, face and neck ${ }^{[18]}$. In the cases as for the cases in our study, localization of lesions was seen in the head and hands in three cases (11.1\%), in hands and arms in $23(85.2 \%)$ cases, in the abdominal region in one case (3.7\%). As the findings offer, the lesion was more frequently seen in the hands; which can be attributed to the active use of hands and arms when dealing with animal meats. At the same time, the presence of cuts on the hands during contact with animal products may increase the risk of anthrax ${ }^{[19]}$.

Vital signs of the cases were interpreted according to the values of fever, pulse blood pressure and respiration. When vital signs were evaluated, it was seen that fever values of 12 patients were high. Laboratory findings of four patients in a study have been reported as normal. A patient, whose blood pressure was known, died as a result of cardiac arrest; his low arterial pressure could be attributed to anthrax-induced sepsis. The values of patients with known blood pressure, pulse and respiratory values were not associated with anthrax. Özkol et al. (2014) have stated that although there was no specific laboratory findings other than Gram staining and culture, C-reactive protein (CRP), sedimentation rate and white blood cell values were generally high in some studies, which supported our study ${ }^{[8]}$. Accordingly, CRP values were reported above the normal values (normal value 5-10 mg/L) in 10 cases (37\%) in our study. WBC values were reported to be higher than $10.000 / \mathrm{mm}^{3}$ in 12 cases (44.4\%). Sedimentation rates of 7 patients (25.9\%) whose sedimentation rates were known exceeded the normal values (> $20 \mathrm{~mm}$ ). High fever in $12 \mathrm{pa}$ tients may be associated with these blood values. Clinical diagnose of cutaneous anthrax may be possible with the help of epidemiological history of the cases and the existence of characteristic lesions. Definite diagnosis is made by examining the samples taken from the lesions ${ }^{[20]}$. As a result of microbiological examinations for definite diagnosis, three patients had positive polymerase chain reaction and seven patients had positive Gram staining results. Treatment with antibiotics was planned in all patients.

Anthrax is not a resistant bacterium unless it is transmitted by natural means and there are genetic manipulations for bioterrorism, so penicillin and its derivatives are the first drugs to be preferred in treatment ${ }^{[21]}$. Three patients underwent surgery in addition to antibiotic treatment. One of the cases was diagnosed with anthrax and was admitted to the anesthesia intensive care unit and cardiopulmonary resuscitation was applied to the patient on the second day of hospitalization. Despite all interventions, the patient died due to the development of Bacillus anthracis sepsis following cutaneous anthrax (Table 1). Cutaneous anthrax may progress up to $20 \%$ of septicemia cases if it is not treated and it may have fatal consequences $^{[22]}$. When the reviewed cases are examined, it is seen that antibiotic treatment upon exposure to anthrax requires surgical intervention in some cases, even if it is seen as endemic. It is also a serious public health problem that may result in 
death. When the distribution of cutaneous anthrax is examined according to years, it is clear that it still poses a current problem in our country.

\section{CONCLUSION}

In conclusion, anthrax, which should be compulsorily reported, is an infectious disease widely seen as a result of broad husbandry in our country. Although we are a developing country, the rise in cases of anthrax is posing a threat to Turkey, as well as a problem in terms of public health. Necessary measures should be taken to prevent the disease in order to decrease the mortality and morbidity related to the disease. Cattle, sheep, goats, equidae and pigs in the region where infection occurs should all be vaccinated over the course of five years ${ }^{[23]}$. The most important field of activity of the Ministry of Health in order to reduce the incidence of anthrax cases is based on the principle of public education and awareness. Thus, studies in this direction are carried out in parallel with in-service trainings ${ }^{[24]}$. This gives a great responsibility to family physicians and public health nurses as it is a risk for public health.

\section{ETHICS COMMITTEE APPROVAL}

This type of study is not required ethical approval.

\section{CONFLICT of INTEREST}

The authors declare that they have no conflict of interest.

\section{AUTHORSHIP CONTRIBUTIONS}

Concept and Design: TŞ, AÇ

Data Collection or Processing: TȘ, AÇ

Analysis/Interpretation: TS, AC

Literature Search: TS, AC

Writing: TS

Final Approval: TŞ, AC̣

\section{REFERENCES}

1. Ertek M. Şarbonun ülkemizdeki durumu. ANKEM Derg 2011;25(Ek 2):88-91.

2. Öğütlü A. Şarbon. J Clin Exp Med 2012;29:155-62.

3. Karayılanoğlu T, Kenar L, Ortatalı M, Öztuna A. Şarbon şüpheli pakete nbc laboratuvarının yaklaşımı: olgu sunumu. Türk Hij Den Biyol Derg 2006;63(1):165-9.
4. Karakoç Ç, Keser M, Somer A, Gürler N, Akman A, Çalışkan $B$, et al. Çocukluk çağında deri şarbonu: bir vaka takdimi. Flora 2007;12(1):52-56.

5. Turnbull PC, Kramer JM, Melling J. Bacillus. In: Baron S. (ed). Medical Microbiology. Galveston (TX): University of Texas Medical Branch at Galveston, 1996.

6. Yeşilbağ Z, Kader Ç. Deri şarbonu: bir olgu sunumu. Klimik 2014;27(3):114-7.

7. Turhanoğlu NM, Bayındır Bilman F, Kutlu Yürüker S. Diyarbakır'da saptanan dört kütanöz şarbon olgusu. Mikrobiyol Bul 2013;47(3):538-543.

8. Özkol Uce H, Karadaş S, Sünnetçioğlu M, Ceylan MR, Çalka Ö, Güdücüoğlu H. Yatırılarak takip edilen 63 deri şarbonu olgusunun klinik ve laboratuvar bulgularının değerlendirilmesi: Türkiye'de deri şarbonu karakteristiği. Türkderm 2014;48:197-203.

9. Şahin ST, Mete AÖ, Karaoğlan I. Şarbon tanısı göz ardı edilmiş olguda cerrahi sonrası sepsis tablosu. MJIMA 2018;7.

10. Güler H, Alyanak A, Yılmaz E. Deri şarbonu: 14 olgunun değerlendirilmesi. Klimik 2011;24(3):176-8.

11. Metan G, Uysal B, Coşkun R, Perçin D, Doğanay M. Şarbon meningoensefaliti: bir olgu sunumu ve Türkiye literatürünün derlenmesi. Mikrobiyol Bul 2009;43(4):671-6.

12. Balkan ÇE, Çelebi S. Doğu Anadolu Bölgesinde şarbon etkeni ve seroprevalansının araştırılması. Türk Mikrobiyol Cem Derg 2018;(1):52-9.

13. Meriç $M$, Willke A. Gebze'de şarbon. Infeksiyon Derg 2008;22(1):1-9.

14. Halk Sağlığı Genel Müdürlüğü. Accessed date: 12.11.2018. Available from: https://hsgm.saglik.gov.tr/depo/birimler/zoonotik-vektorel-hastaliklar-db/zoonotik-hastaliklar/5-Sarbon/3-istatistik/Web_Sarbon_haritasi.pdf.

15. Aydın Gayretli ZG, Çiftçibaşı AG, Özkaya E, Aksoy F, Yılmaz MA, Aktaş D. Şarbon: Temas Sonrası Çocuk Olguların Yönetimi. Journal Pediatr Inf 2018;12(1):20-4.

16. Mwakapeje ER, Hogset S, Softic A, Mghamba J, Nonga $H E$, Mdegela RH, et al. Risk factors for human cutaneous anthrax outbreaks in the hotspot districts of Nothern Tanzania: an unmatched case-control study. R Soc Open S 2018;5(9):180479.

17. Arapovic J, Skočibušić S, Jelavic B, Ivanković $H B$, Juriç $M$, Mamic $D$, et al. Two cases of human cutaneous anthrax in Bosnia and Herzegovina, September 2014. Euro Surveill 2015;20(7):2-4.

18. Aktürk AŞ, Bilen N. Infeksiyöz ajanlara bağlı ölümcül olabilen deri hastalıkları. Turk Klin I Dermatol-Special Topics 2010;3(3):65-72.

19. Woods CW, Ospanov K, Myrzabekov A, Favorov M, Plikaytis B, Ashford DA. Risk Factors For Human Anthrax Among Contacts Of Anthrax-Infected Livestock In Kazakhstan. Am J Trop Med Hyg 2004;71(1):48-52.

20. Gül S, Kuşcu F, Öztürk $D B$, Gürbüz $Y$, Tütüncü $E$, Şencan i. Şarbon salgını: yedi olgunun değerlendirilmesi. Flora 2009;14(1):43-7. 
21. Kılıç S. Biyolojik silah olarak bakteriler: "Kategori A ajanlar". Turk Hij ve Den Biyol Derg 2006;63:21-46.

22. Chakraborty PP, Thakurt SG, Satpathi PS, Hansda S, Sit S, Achar A, et al. Outbreak of cutaneous anthrax in a tribal village: a clinical-epidemiological study. I Assoc Physicians India 2012;60:89-93.

23. T.C. Cumhurbaşkanlığı Resmi gazete. Şarbon Hastalığına Karşı Korunma Ve Mücadele Yönetmeliği. Accessed date: 13.04.2019. Available from: http://www.resmigazete.gov. tr/eskiler/2011/12/20111223-5.htm.

24. Uzun R, Safran A, Buzgan T. Zoonotik hastalıkların insanlardaki durumu. I. Türkiye Zoonotik Hastalıklar Sempozyumu Kitabı. I. Türkiye Zoonotik Hastalıklar Sempozyumu; 2006, Ankara, Türkiye, 2006:15-33.

\section{Address for Correspondence/Yazıșma Adresi}

Tuğçe SAHIN

Sakarya Üniversitesi, Sağlık Bilimleri Fakültesi Halk Sağlığı Hemșireliği Anabilim Dalı,

Sakarya-Türkiye

E-mail: tugcesahin.6767@gmail.com 